\title{
A DIGITÁLIS MODELL KONTROLLJA A KÖZBESZERZÉSI ELJÁRÁSOKBAN
}

\author{
Szőke Brigitta - Cuprik Vanda
}

\section{Összefoglalás}

Tanulmányunkban a közbeszerzési eljárásokban alkalmazott digitális modellek értelmezésére kerül sor különbözón példákon keresztül. Mivel az eljárás elókészitése során nem lehet tudni, hogy milyen ajánlatok érkeznek a piaci szereplöktöl, és a lineáris gondolkozás, nem érvényes, ezért az elökészités során a digitális modellel történō széleskörü hatásvizsgálatot kell végezni és az értékelési módszer ismertetésénél gondosan meg kell határozni nemcsak az alkalmassághoz. sұüleséges minöségi paraméter értékét, hanem azt az értéket is, amelynél kedvezöbb ajánlati tartalmi elemet az ajánlatkérö csak ezzel az értékekel vesz figyelembe. Mint minden modellezésnél, itt is fontos, hogy elemzésre alkalmas bemenö adatok legyenek megadva, és a következtetéseket ezekere (valamint a modell tulajdonságaira) tekintettel kerüljenek megfogalmazásra. Amennyiben nincs általános törvényszerüség, akkor a következtetéseknél közölni kell azok érvényességét - a félreértések elkerïlésére. Ugyancsak tudatában kell lenni, hogy a beszerzési eljárások elökészitése során nem lehet tudni, milyen ajánlatok. fognak érkezni. A modell extrém input adatok esetén is müködik, de az eredményeinek felhasználhatósága kétséges. Tulajdonképpen minden lefolytatott köz̨beszerzési eljárás során gyülnek a tapasztalatok, melyeket a hasonló tárgyú követkęő eljárásban fel lehet használni.

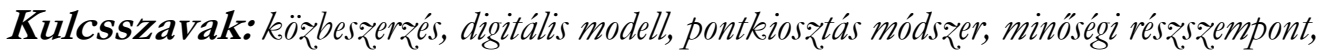
JEL: G0, G3

\section{CONTROL OF THE DIGITAL MODEL IN PUBLIC PROCUREMENT PROCEDURES}

\begin{abstract}
In our study, digital models used in public procurement procedures are interpreted through various examples. As it is not possible to know what bids are being received from market participants during the preparation of the procedure, and linear thinking is not valid, a wide-ranging impact assessment of the digital model should be carried out during the preparation and the evaluation method should be carefully defined not only for suitability. the value of the quality parameter, but also the value below which the contracting authority considers the more favorable tender content element only with this value. As with all modeling, it is important that inputs suitable for analysis are provided and conclusions are drawn with these (as well as the properties of the model) in mind. If there is no general legality, the conclusions should state their validity - to avoid misunderstandings. You should also be aware that it is not possible to know what bids will be received during the preparation of procurement procedures. The model also works for extreme input data, but the usability of its results is questionable. In fact, experience is gained in all public procurement procedures that can be used in the next procedure with a similar subject.
\end{abstract}

Keywords: public procurement, digital model, point allocation method, quality sub-aspect, JEL: G0, G3 


\section{Bevezetés}

„Gazdaságelméleti szempontból a közbeszerzés a piaci szerkezetek egy különleges formáját jelenti." (Török et al. 2007) A tanulmányunk célja az ajánlatkérők által alkalmazható, a Közbeszerzési Hatóság által támogatott értékelési módszerek közül a digitális modell alkalmazását átfogóan ismertetni. „A gazdaságtan legfontosabb feladata a közbeszerzési piac azonosítása, elemzése, melynek során választ kaphatunk arra a kérdésre, milyen területen van változtatási lehetőségünk, figyelemmel a szabályozási környezetre, s a szereplők mit tekintenek problematikus területnek, mit éreznek a rendszer gyengeségének." (Tátrai, 2007) Először is fontos megemlíteni, hogy milyen esetekben jelenik meg Közbeszerzési Törvény szerinti eljárás. Az első hazai, kizárólag és kifejezetten közbeszerzési tárgyú jogforrás a közbeszerzésekről szóló 1995. évi XL. törvényvolt.” (Arató, 2014) „Közbeszerzésnek minősül a közbeszerzési szerződés, valamint az építési vagy szolgáltatási koncesszió e törvény szerinti megkötése. A közbeszerzési szerződés tárgya árubeszerzés, építési beruházás vagy szolgáltatás megrendelése lehet.” (Kbt. 8. \(1) bek.) „A közbeszerzési szerződés az értelmező rendelkezések szerint a Kbt. szerinti ajánlatkérő által, írásban megkötött, árubeszerzésre, szolgáltatás megrendelésre vagy építési beruházásra irányuló visszterhes szerződés.” (Kbt. 3. \$24. pont) A tanulmány jelentőségét az adja, hogy a közbeszerzési eljárásokban évente mintegy 3600 milliárd forint értékű szerződéskötésre kerül sor. Ezekben az eljárásokban a nyertes ajánlattevő - akivel szerződéskötésre kerül sor - kiválasztását döntően befolyásolja az eljárásban alkalmazott értékelési módszer, hivatkozik erre a Közbeszerzési 2015. évi CXLIII. törvény. Ezeket a befolyásoló tényezőket, hatásaikat mutatjuk be, ezáltal a cikk és a digitális modellezés alapján útmutatást adjunk a célszerű alkalmazásra. Az alkalmazáskor felmerülő problémákra konkrét esetekkel is rámutatunk, melyekkel a közbeszerzési eljárások előkészítésénél találkozni lehet. A modell másik jelentősége, hogy segítséget nyújt az alkalmazandó eljárásrend helyes meghatározásához. Az ajánlatkérő kötelezettsége, hogy gondos és dokumentált előkalkulációval meghatározza a várható ellenszolgáltatás értékét (a Kbt. ezt becsült értéknek nevezi, de a becslés nem alkalmazható), és a részekre bontás tilalmát is figyelembe véve ez alapján alkalmazza a nemzeti vagy uniós eljárásrendet, illetve a közbeszerzési értékhatár alatti igény esetén versenyeztetés is jogszerű, olvasható a Közbeszerzési Hatóság 2017 évi országgyúlési beszámolójában. A Közbeszerzési Hatóság 2016/147.sz. útmutatója alapján típushibának számít, hogy a becsült érték meghatározása során nem veszik figyelembe a minőségi értékelési szempontok által potenciálisan generált, az ún. minőségi felárnak nevezett árnövekményt, és az eljárás lefolytatása után a nyertes ajánlattevővel nem lehet jogszerűen szerződést kötni. Egy rövid példával magyarázva: az alkalmassági követelményeket kielégítő ajánlat szokásos piaci ellenértéke az előkalkuláció szerint 46 millió $\mathrm{Ft}$, de a minőségi követelményeket mindenben kielégítő nyertes ajánlattevő 57 millió Ft-os ajánlattal nyer - a szerződés megkötése a közbeszerzési törvény megkerülését jelentené.

\section{Anyag és módszer}

Az anyag és módszertan fejezetben a digitális modell általános bemutatását és alkalmazását ismertetnénk. A modellezés célja valamely jelenség vagy objektum tulajdonságainak vizsgálata a valóságos körülményeknél kedvezőbb feltételek és így alacsonyabb költségek mellett. A körülmények közé sorolhatjuk az előfordulási esetek számát is - nagyon sok esetben a természetes előfordulásra ritkán kerül sor (földrengés, cunami). A modellezés célja sokféle lehet: prognosztizálás, demonstráció, kutatás stb. A modellkészítés során a legfontosabb annak meghatározása, hogy a valóság 
vizsgált részletéből mely elemeket építsünk be a modellbe, ugyanis csak ezekre lesz érvényes a modellezésből eredő megfigyelés.

A modellezés alapvetően lehet:

- minta, a valós objektum vagy jelenség eltérő méretben történő megvalósítása és ezen vizsgálatok végzése;

- szimuláció, a vizsgálandó objektum vagy jelenség olyan matematikai leírása, amely tulajdonságai megfelelnek az eredetiének (legalábbis a vizsgálni kíván szempontokból).

A szimuláció lehetôvé teszi változatos körülmények (állapot, környezeti feltételek, külső hatások, belső tulajdonságok stb.) közötti tulajdonságok vizsgálatát. Amennyiben a leíró matematikai rendszert digitális számítógép segítségével alkalmazzuk, akkor digitális szimulációról beszélünk. A tanulmányunkban alkalmazott modellnél nem kellett a valóság elemei között választani, a PC kapacitása képes az összes lehetséges esetet kezelni - így a modell teljes értékủ a vizsgált jelenség tekintetében.

Az eljárás-előkészítést elősegítő digitális értékelő modellt MS Office - Excelben készítettük el a standard függvények alkalmazásával, Windows 10 Enterprise verzióban. A hardver-igény minimális, bármely PC-n futtatható. A modell három eltérő ajánlat egyidejű elemzésére alkalmas - az ajánlatok számát növelni szükségtelen, mert a három ajánlattal már az is szimulálható, ha arányosításoknál egy ajánlat a legjobb és a legrosszabb között helyezkedik el. A modellbe három értékelési részszempontot építettünk be, az ajánlati árat és két minőségi részszempontot. Ennek indoka, hogy az ár minden esetben szerepel az értékelési szempontrendszerben, a két minőségi részszempont pedig lehetôvé teszi, hogy ezek különálló hatásait vizsgáljuk.

A modell mindhárom értékelési részszempontra tudja alkalmazni:

- az arányosítás módszereit

- az egyszerúsített arányosítási módszereket

- pontkiosztást (itt kivétel az ajánlati ár).

Az Input felületen lehet megadni, hogy a vizsgált értékelési feltétel-rendszeren belül milyen súlyszámok és milyen módszerek kerüljenek alkalmazásra.

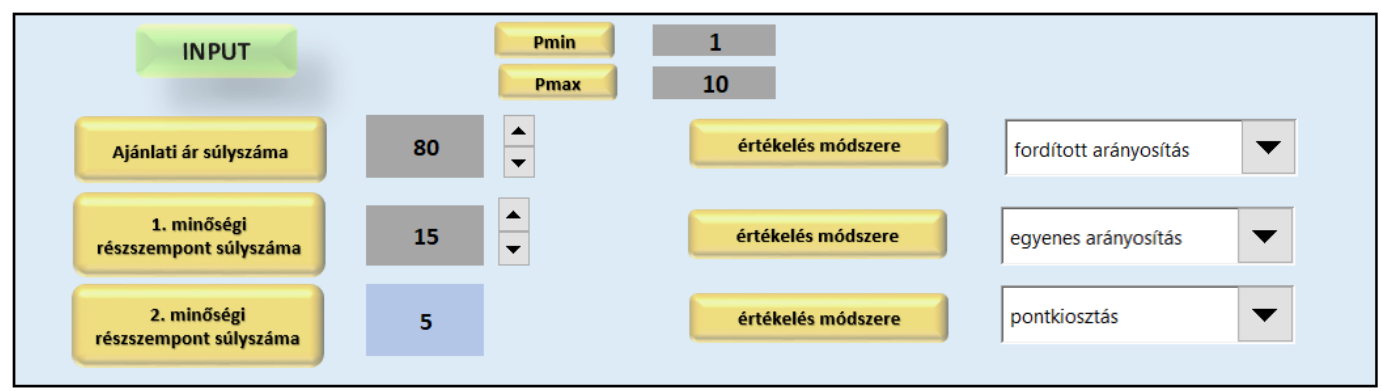

\section{1. ábra Input felület}

Forrás: saját szerkesz̨tés

Az 1. ábra egy olyan értékelést mutat be, melyben az ár fordított arányosítással kap pontot és ennek a súlyszáma 80 , az 1 . minôségi részszempont (pl. az elvárt jótállás feletti többletjótállás hónapokban) egyenes arányosítással, a 2. minőségi szempont pedig pontkiosztó táblázatból (azaz abszolút módszerrel) kap pontot (pl. kipufogó-gáz emissziós érték). A súlyszámok és a ponthatárok is egyértelműen leolvashatók az ábráról. A modell működését és eredményeit egy konkrét eseten mutatjuk be. 


\section{Eredmények}

Az ajánlatkérő jármú karosszéria-alkatrészt kívánt beszerezni, a mintadarab gyártási költsége 300 ezer Ft + áfa volt. A 150 db beszerzésének becsült értékét ez alapján 150 x 300 ezer Ft = 45 millió forintban határozták meg. A kötelezően alkalmazandó minőségi értékelési szempontként az elvárt 12 hónap jótállást meghaladó többletjótállást határozták meg, 30-as súlyszámmal. Két érvényes ajánlat érkezett - és mégsem kerülhetett sor szerződéskötésre! Az ajánlatok:

$\begin{array}{llll}\text { - „, X Kft.” } & \text { ajánlati ár: } & 46500 \text { ezer Ft, többletjótállás } & \text { nincs, } \\ \text { - „,W Bt.” } & \text { ajánlati ár: } & 61250 \text { ezer Ft, többletjótállás } & 24 \text { hónap. }\end{array}$

Az értékelést a modellel elvégezve (a 2. minőségi szempont inaktív mivel a súlyszáma nulla) az alábbi összpontszámok adódnak, amelyet a 2. ábra illusztrál.

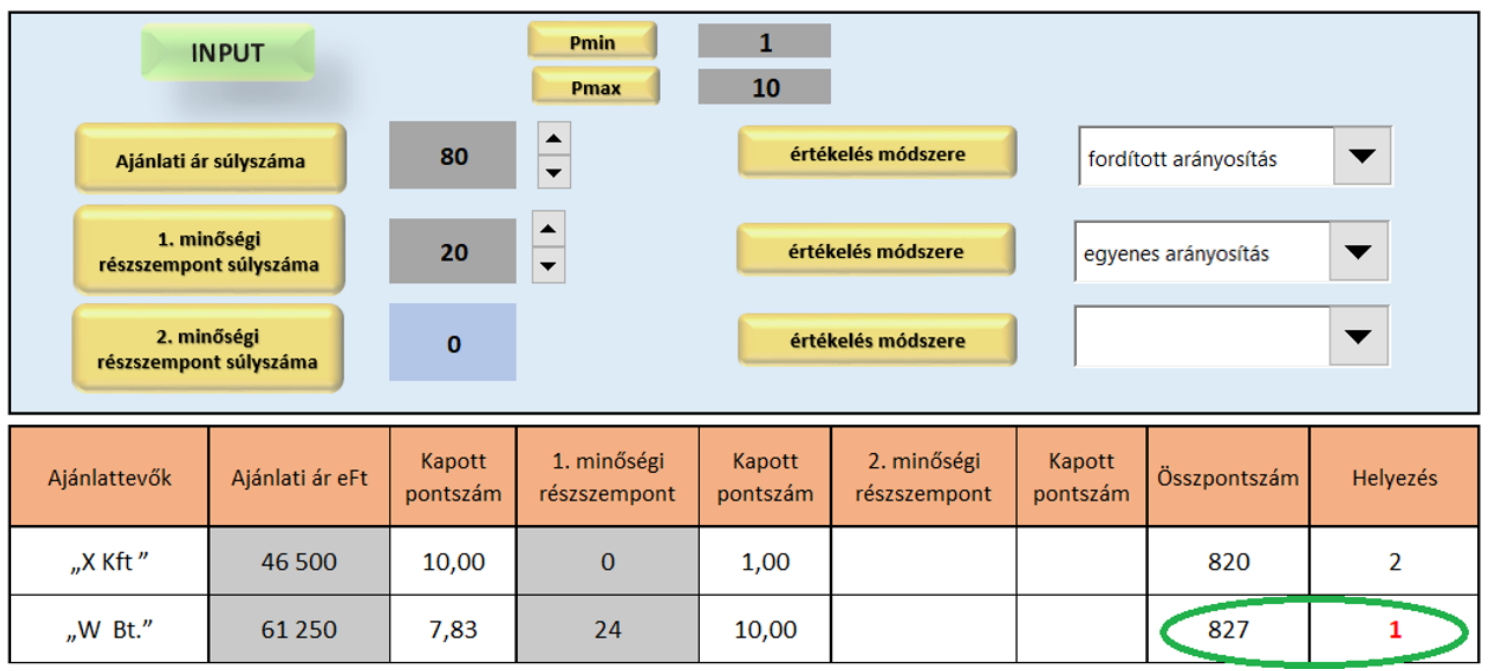

2. ábra Az értékelési modell elvégzésének összpontszámai

Forrás: saját sz̧erkesztés

Meglepő, hogy a 15 millió forinttal drágább ajánlat nyert, mivel összpontszáma a legnagyobb. A W Bt. az ajánlati felhívás szerinti (értékelés alá kerülő) maximális 36 hónapos jótállásra tette ajánlatát, azaz 24 hónapos többletjótállásra a maximális 10 pontot kapta. A problémák két témakörben jelentkeznek ebben a példában:

- a nyertes ajánlattevővel a szerződés nem köthető meg (fedezet-hiány, illetve a közbeszerzési értékhatárt meghaladó ajánlati ár miatt), az eljárás eredménytelen, nincs jogszerú módja annak, hogy a reálisabb46,5 millió forintos ajánlatot tevő céggel szerződést kössenek. Tehát az eljárás előkészítésére és lefolytatására fordított idő, pénz energia kárba veszett, az ellátás nincs biztosítva,

- a közpénz hatékony felhasználására vonatkozó követelmények miatt felmerül, hogy racionális gazdasági döntés-e mintegy 15 millió forinttal többet fizetni az elvárt jótállást meghaladó többlet-jótállásért.

A gazdasági racionalitás megítélésével kapcsolatban az ajánlatkérőnek rendelkeznie kell akár saját tapasztalat, akár szakirodalmi adatok alapján a beszerzés tárgyát képező alkatrész, fődarab stb. üze- 
meltetéséhez kapcsolódó költségekről adatbázissal, hogy információk alapján megítélhesse: az alkatrész beszerzését követő 2. és 3. évben milyen költségei merültek fel melyeket a minőségi felárért megvásárolt többletjótállás kiváltana. Általában ez az üzemviteli-kontrolling (üzleti tervezés) típusú adatbázis rendelkezésre áll a rendszeresen használt alkatrészek (pl. gumiabroncs, generátor) esetén. Az általunk megismert eljárásoknál típushiba, hogy a 2. és 3. évben az adott alkatrészre átlagosan felmerült összes költséget tekintik összehasonlítási alapnak - holott csak a jótállási kötelezettség alá eső meghibásodásokét lenne szabad. Széchenyi 2020 - Útmutató a Kbt. 77. \(1) bekezdése szerint az üzemviteli kontrolling rendszerek igen ritkán minősítik, hogy adott költséget előidézô esemény jótállási körbe tartoznak-e (amennyiben lenne többletjótállás) - a cél a költségek figyelése, nem az okok elemzése. Mindezek miatt is fontos a digitális modell előkészítési szakban történő alkalmazása, ehhez értő beszerzés-gazdaságossági munkatárs bevonása.

A modell alkalmas bármilyen árral dolgozni (ahogy az előző konkrét példában is láttuk), a megértést viszont relatív mutatószám jobban elősegíti: ezért a minőségileg csak megfelelő (azaz $\mathrm{P}_{\min }$ pontot elérô) ajánlatban az ár 100 egység lesz, és a maximális minőségủ másik ajánlat holtversenyt eredményező ára (pl. 160 egység) szemléletesen mutatja a minőségi felárat (60 egység), célszerűen százalékban: 60 százalék. Ezzel a modell segítségével tett megállapítások függetlenné válnak az ajánlati ár abszolút mértékétől. A minőségi felár elsősorban a súlyszámoktól, másodlagosan a pontszám-tartománytól függ. A következő modell-eredmény mutatja be (3. ábra) pl. a 80-20-as súlyszámok esetén az árat fordított arányosítással értékelve a minőségi felárat:

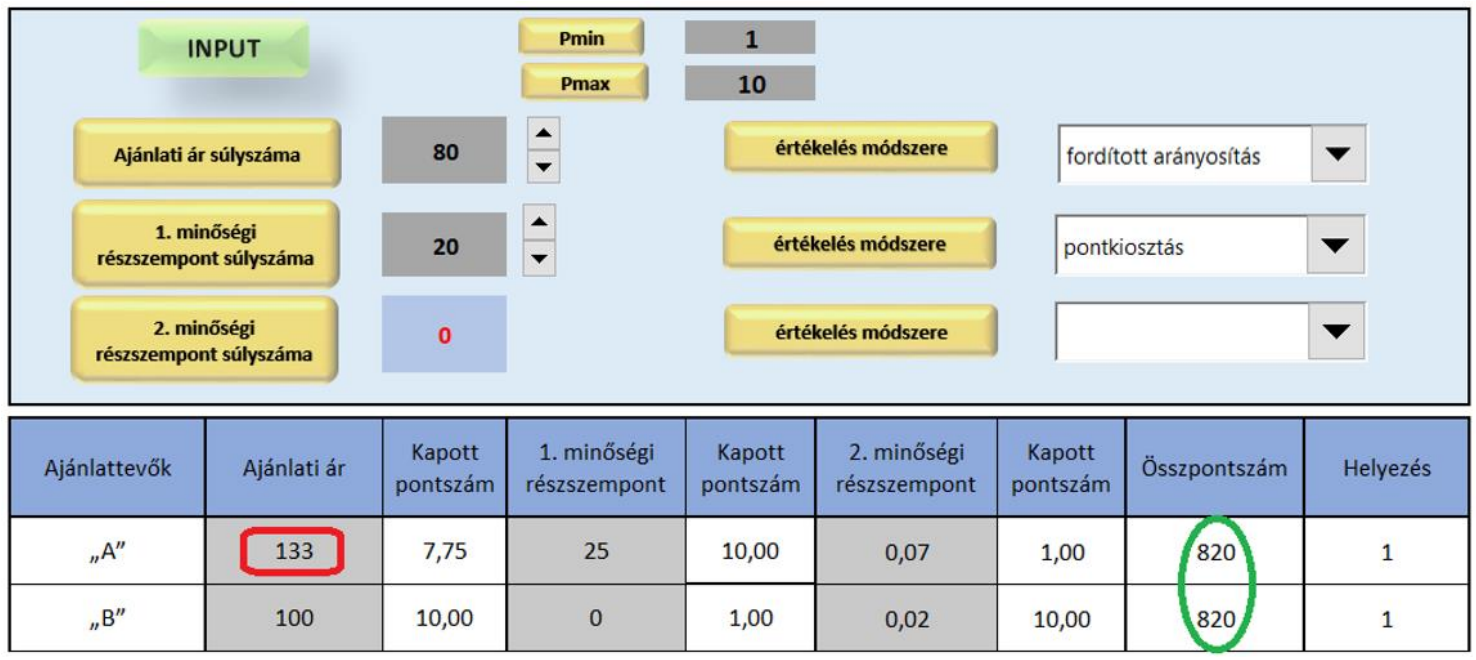

3. ábra Minőségi felár modell-eredmény

Forrás: saját sz̧erkesz̧tés

Az „A” ajánlattevő 133-as pénzegységnyi ajánlati ára (pirossal jelölve) esetén a két ajánlat összpontszáma azonos (lásd zöld jelölést) - tehát a 80-20-as súlyszámpár esetén a minőség felára 33 százalék. Megjegyzendő, hogy ezt az értéket nem befolyásolja a 1. minőségi részszempont esetén alkalmazott pontkiosztás - akár arányosítással, akár pontkiosztással kapta meg az egyik a $\mathrm{P}_{\max }$, a másik a $\mathrm{P}_{\min }$ pontot, az összpontszámra már nincs hatással a pontkiosztás módszere. Arra az esetre, amikor nem a teljes pontszám-tartományon kerülnek a pontok kiosztásra, a későbbiekben ki fogunk térni. Ugyancsak felhívnánk a figyelmet, hogy a modell alkalmazását az összpontszámok esetén fennálló holtverseny szituációval alkalmazzuk, annak ellenére, hogy a közbeszerzési törvény erre az esetre tartalmaz rendelkezést: az a nyertes, amely ajánlatban az ár (vagy költség) részszempontra több pontot kapott. Azaz holtverseny esetén az ár dönt. De a modell esetén zavarná az 
olvasót pl. 12999 millió Ft-os ár, a cikkben tett megállapítások pedig így is érvényesek, hiszen ha a holtversenyben lévő ajánlatok közül az egyik ára csak 1 forinttal csökken, máris nyertes, gyakorlatilag azonos minőségi felár-összeggel. A modellt eltérő súlyszámpárokkal futtatva az alábbi összefüggést kapjuk.

Az ábrából megállapítható, hogy a minőségi felár:

- döntően a minőségi szempont(ok) súlyszámától függ,

- a súlyszám növekedéssel hatványozottan nő,

- 50-es súlyszám esetén végtelen az értéke,

- elhanyagolható mértékben hat rá a $\mathrm{P}_{\min }$ pontszám $(0,1)$ változása.

A 4. ábra alapján már érthető az „X Kft.” és „W Bt.” ajánlattevők konkrét ajánlataival bemutatott értékelés eredménye: mivel a W Bt. 61250000 Ft-os ajánlata csak 32 százalékkal haladta meg a másik ajánlat árát, azaz alacsonyabb mértékben, mint a 80-20-as súlyszámoknál a minôségi felárat jelentő 33\%, ezért a „W Bt.” drágább ajánlat a nyertes.

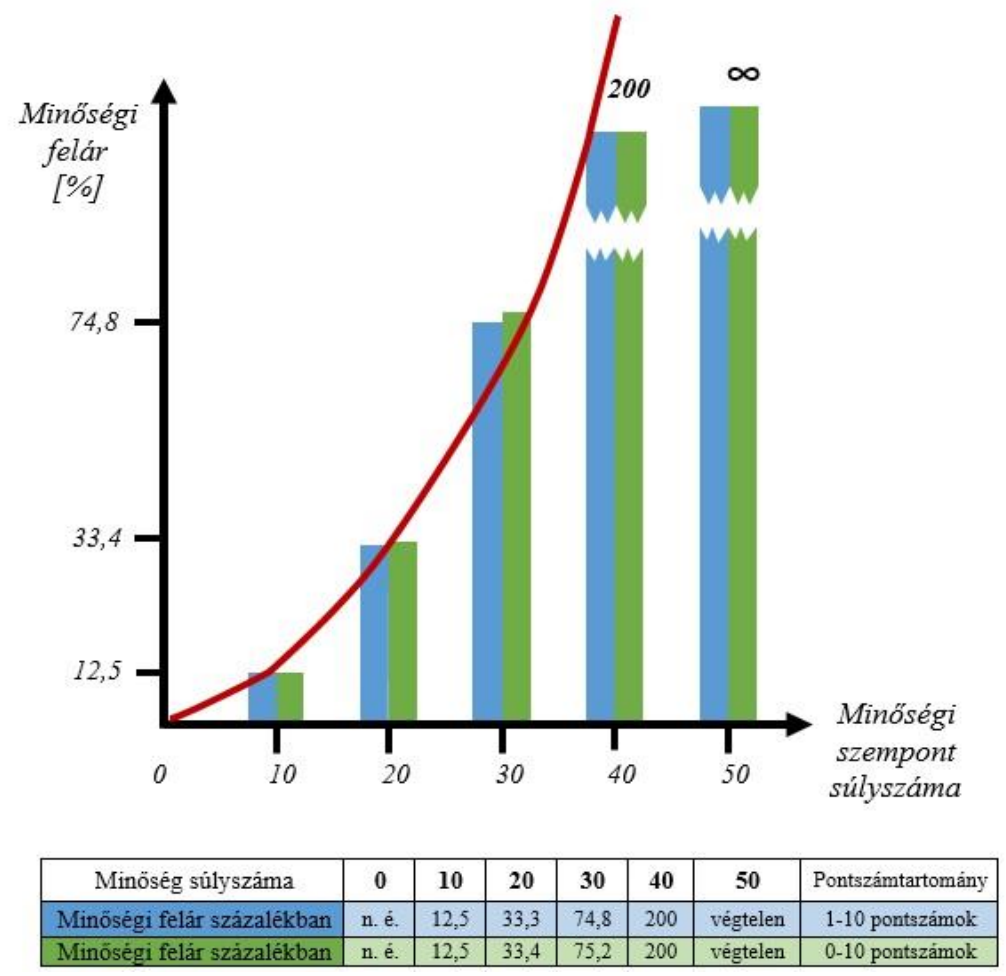

4. ábra A modell eltérő súlyszámpárokkal futtatva

Forrás: saját szerkesz̨és

A továbbiakban az 1-10-es pontszámtartományt alkalmazását mutatnánk be (a variációk csökkentése céljából), mivel az eltérés a 0-10 esethez képest tized-százalékos mértékú, azaz elhanyagolható. Az értékelési (rész)szempontokhoz tartozó súlyszámok megválasztása az ajánlatkérő feladata (A pontkiosztás módszere a közbeszerzési eljárásokban egy konkrét példán keresztül c. cikkünk), de egyes beszerzési tárgyaknál korlátokat szabott a jogalkotó, mint például az építési beruházások, a tervező kiválasztására irányuló beszerzési eljárások esetén. Az építési beruházásnál (mely új épület vagy építmény létrehozásán túl a Kbt. 1. sz. mellékletében felsorolt un. szakipari munkákra irányuló beszerzést is magában foglalja) az ellenérték súlyszáma nem haladhatja meg a súlyszámok összegé- 
nek 70 százalékát. Azaz a minőségi értékelési részszempont vagy szempontok súlyszámai összegének legalább 30\%-ot el kell érnie, ehhez a 4. ábrán a 30-as értéknél 75\%-os minőségi felár tartozik. Az építész szakma egy új épület (óvoda, kórház stb.) esetén számos objektív minőségi értékelési szempontot tud találni (energia-hatékonyság, alkalmazott építőanyagok minősége, környezetvédelmi szempontok stb.) és szubjektív, esztétikai szempontok is értékelhetők, de egy járda-aszfaltozásnál, szociális helység csempével történő burkolásánál, szobafestés-mázolásnál a szakma nem tud meghatározni olyan, az alkalmassági követelményt meghaladó minőségi szempontokat, melynek teljesülése esetén racionális a 75\%-os felár. Az ún. kényszer-megoldásokban jellemzően alkalmazott „minőségi” részszempontok:

- a teljesítésben részt vevő szakemberek többlet-tapasztalata,

- az előteljesítési idő,

- a többlet-jótállás vállalása.

Nézzünk egy példát: városi vasúti pálya felújítására kiírt közbeszerzési eljárásnál az ajánlati ár értékelési résszempont súlyszáma 70, az elvárt 180 napos határidőnél előbbi teljesítés vállalása 20, az elvárt 24 hónapos jótálláson felül vállalt többletjótállás 10-es súlyszámmal kerül értékelésre. A három ajánlattevô ezen részszempontokra adott ajánlatait a modell mutatja be a következő 5 . ábrán, az értékelési paraméterekkel együtt:

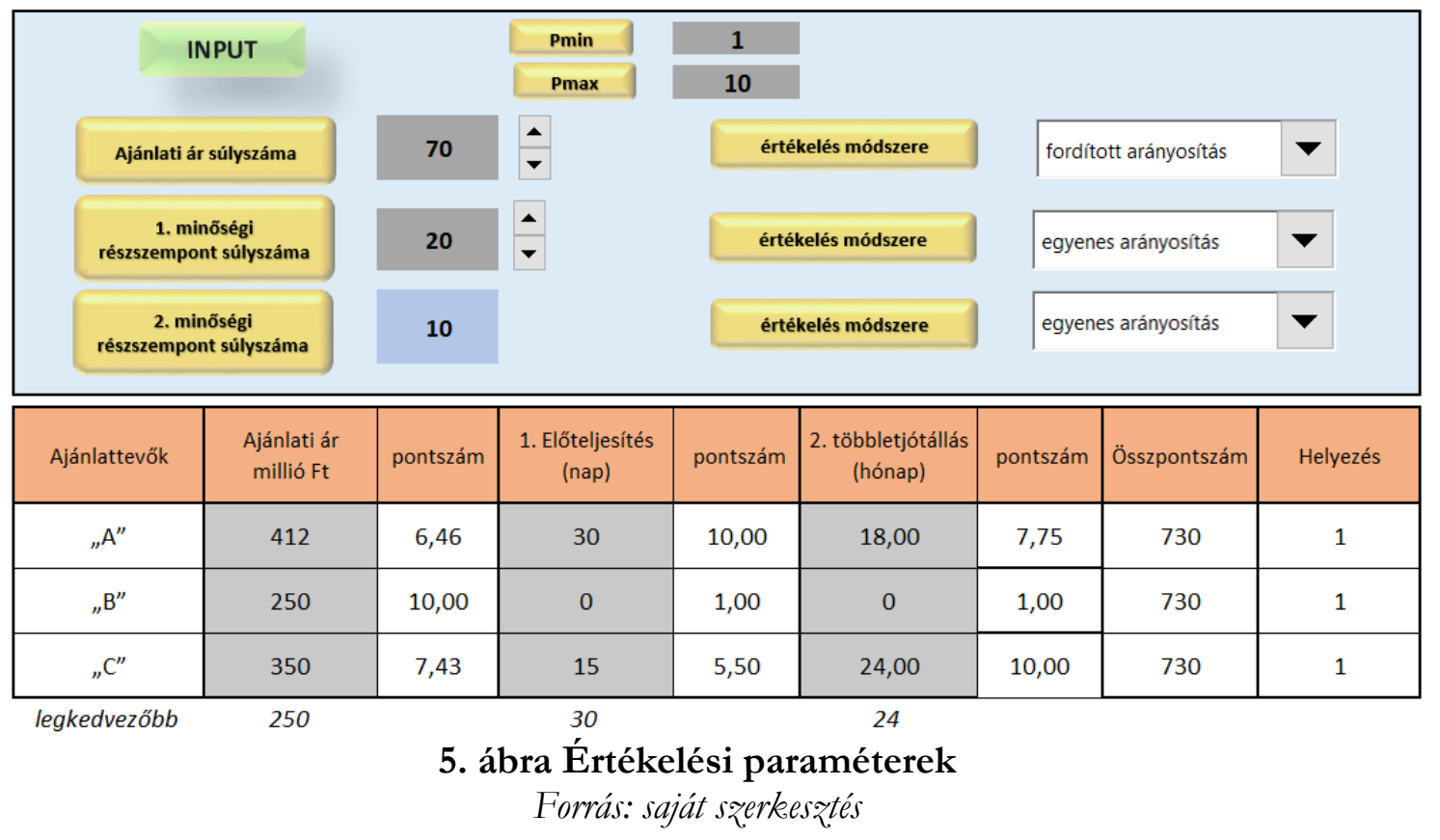

Elemezve a három holtversenyben lévő ajánlatot, felmerül a kérdés, egyrészt, hogy racionális-e az „A” ajánlattevőnk 162 millió forinttal többet fizetni azért, mert 30 nappal korábban átadja (nyilván kevesebb a busz-pótlás költsége) és 1,5 év többletjótállást vállal? Másrészt, ésszerû-e a „C” ajánlattevőnek 100 millió forinttal többet fizetni a + két év jótállásért és a két héttel korábbi átadásért?

A digitális modell az eljárások előkészítési szakaszában rá tud mutatni ezekre a kérdésekre és segíti a minőségi értékelési szempontok megfelelő meghatározását. A kérdések megválaszolása igen komoly előzetes gazdasági-pénzügyi elemzésre van szükség, melyhez megfelelő adatbázis megléte előfeltétel. Az előző példákban jellemzően két ajánlattevő ajánlatait mutattuk be. A következőkben 
több ajánlat esetén foglalkozunk a minőségi felár megállapításával. A minőségi felár a definíciójából eredően csak a nyertes ajánlattevőnél lép fel, és eddig vizsgálataink szerint döntően a súlyszámoktól függ. A digitális modell teljes körű felhasználása, a modell érvényességi tartománya és esetleges korlátjainak megismerése szükségessé teszi, hogy több ajánlattevő esetén is vizsgálatokat végezzünk és következtetéseket határozzunk meg. Minden szimuláció veszélye, hogy a felhasználók - felületes ismereteik miatt - az eredményeket olyan esetekre is alkalmazzák, melyekre a modellezés nem terjed ki, mely hatásokat a modell nem vesz figyelembe. A modellnél az ár értékelése egyszerúsített fordított arányosítással történik minden esetben, ahogy a valóságban is. Ennek oka, hogy az ajánlatkérôk sosem az árkülönbözetben érdekeltek, hanem magában a beszerzési árban - minden Üzleti Terv, finanszírozási vagy támogatási szerződés, forrást biztosít és nem forráskülönbözetet.

Vizsgáljuk meg azt az esetet, amikor a minőségi részszempont értékelése pl. a Pmin és Pmax képlettel történik, a pontok kiosztásra kerülnek (ha van legalább kettő eltérő ajánlat), továbbá három vagy több ajánlattevő van. A vizsgálat oka, hogy a harmadik és további ajánlattevők összpontszámát befolyásolja a minőségi szempontra adott ajánlatok tartalmi elemeinek különbsége. Az eljárás közúti járművek beszerzése, a minőségi szempont a fajlagos üzemanyag-fogyasztás. Ez minél kisebb mértékben haladja legalacsonyabb értéket (azaz a piacon kapható legjobb jármûvét), annál több pontot kap. Mivel a legalacsonyabb fogyasztás költségét mindenféleképpen ki kell fizetnie az üzemeltetőnek, a többlet-fogyasztásból eredő többletköltség értékelése logikus az abszolút fogyasztás értékelése helyett. Ezen pontkiosztást grafikusan a 6. sz. ábrán mutatjuk be.

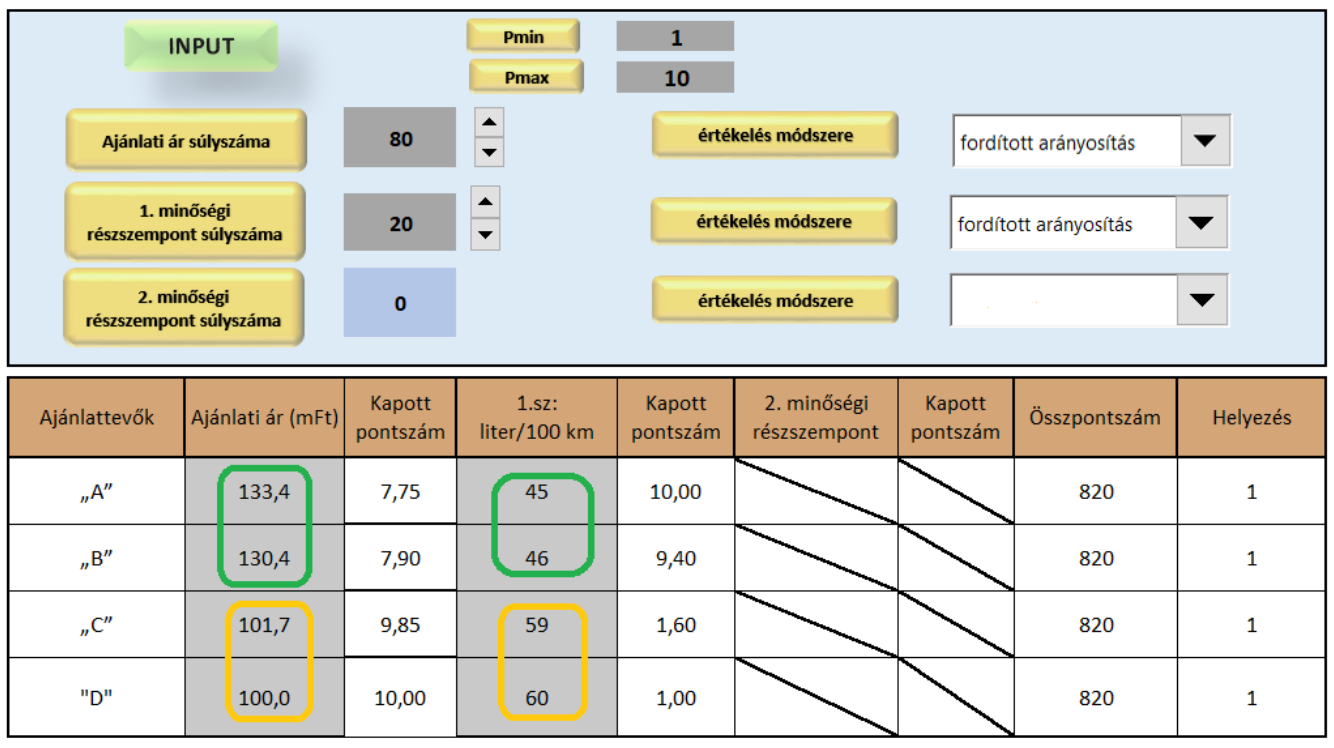

6. ábra Modellszámítás

Forrás: saját szerkesz̨tés

A négy ajánlat igen eltérő (33\%-os mértékủ) sávba eső minőségi ajánlattal (üzemanyag- fogyasztás liter $/ 100 \mathrm{~km}$ ) is holtversenyben van. Ami érdekes: 1 liter üzemanyag-megtakarítás a minőségi értékelési szempontra érkezett ajánlatok kedvező tartományában („A” és „B” ajánlattevők, lásd zöld színnel kiemelve) 3\%-os felárral érhető el (ami a példában 3 millió Ft-os vételár-többletet jelent), míg a tartomány kedvezőtlenebb részén (narancs-színnel kiemelve „C” és „D” ajánlattevők) ugyanilyen mértékủ megtakarításhoz elég $1,7 \%$ is. Természetesen a jármú üzemeltetése során nem a fogyasztás-különbözet, hanem a tényleges fogyasztás költsége fog felmerülni - de a modell által kimutatott hatást a gazdasági elemzésekben nem alkalmazzák, hanem lineárisnak tekintik a felár és a „többletfogyasztás” összefüggését. Hogy függ ez a súlyszámtól - a kérdés logikus, hiszen eddigi 
vizsgálataink alapján a minőségi felárra a legnagyobb hatással a súlyszámok vannak. Az előző minta 90-10-es súlyszámokkal a következő eredményt adja:

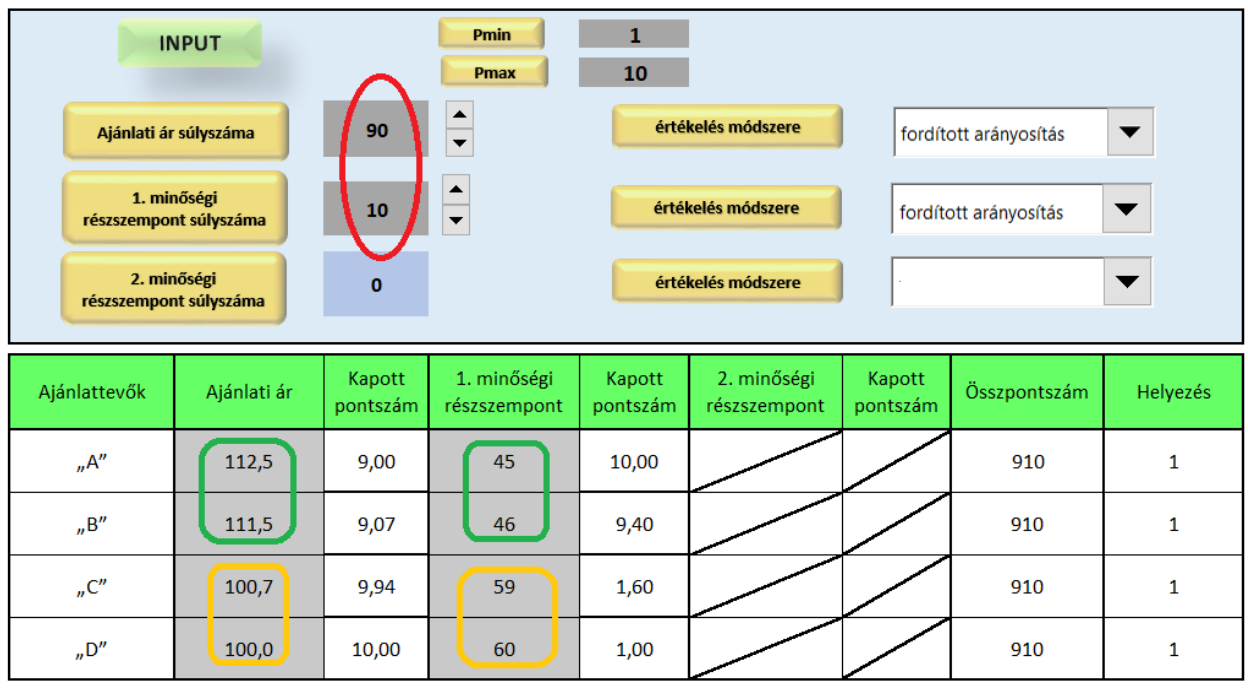

7. ábra Modellszámítás

Forrás: saját szerkesz̨tés

A modell output szegmensében leolvasható (7. ábra), hogy 90-10-es súlyszámpárnál az 1 liter/100 km-re jutó felár 3\%-ról 1\%-ra, illetve 1,7\%-ról 0, \%-ra változott. Az eredmények alapján megállapíthatom, hogy több ajánlattevő esetén, a minőségi részszempont teljes pontkiosztású képlettel történő értékelése során: a legkedvezőtlenebb és a legkedvezőbb két ajánlat közötti minőségi felár a 4. sz. ábrán bemutatott hatás szerint alakul, további ajánlatok esetén a minőségi felár függ attól, hogy a minőségi részszempont tartalmi eleme hogy helyezkedik el a beérkezett ajánlatok tartományában.

\section{Köveztetések és javaslatok}

Mivel az eljárás előkészítése során nem lehet tudni, hogy milyen ajánlatok érkeznek a piaci szereplőktől, és a lineáris gondolkozás, mint bemutattuk nem érvényes, ezért az előkészítés során a digitális modellel történő széleskörű hatásvizsgálatot kell végezni, valamint az értékelési módszer ismertetésénél gondosan meg kell határozni nemcsak az alkalmassághoz szükséges minőségi paraméter értékét, hanem azt az értéket is, amelynél kedvezőbb ajánlati tartalmi elemet az ajánlatkérő csak ezzel az értékkel vesz figyelembe.

A második javaslatunkat egy példa segít megérteni. A Kbt. lehetősége biztosít arra, hogy az ajánlatkérő az eljárást megindító dokumentációban meghatározza, például, hogy a 24 hónapot meghaladó többletjótállás vállalási ajánlat esetén ez úgy kerül elbírálásra, mintha az ajánlat 24 hónapos ajánlati elemet tartalmazna. Ez azért segíti a reális értékelést, mert különösen jövőbeli (most nem belátható, kockázatosan érvényesíthető) feltételeket az ajánlattevők szívesen vállalnak. Gondoljunk arra is, hogy az ellenérték kifizetése a teljesítéskor megtörténik, a hosszú jótállási kötelezettség meg a távoli jövőbe vész. A működési cash-flow még akkor is javul, ha a nyertes korrekten eleget tesz szerződéses kötelezettségeinek. A modellt a sorba rendezéses pontkiosztás esetén is alkalmas elemzésekre, de erre nem tértünk ki, mivel általános érvényű következtetés nem vonható le. Az ok lehet például második egy jármű 46 liter/100 km-es fogyasztással, de 58 literes fogyasztással is második maradna (az ábrán szereplő négy ajánlat között). Sőt, 59 literes fajlagos fogyasztási ajánlat még a 
„C” ajánlatot is „felhozná” a második helyre! Azaz a sorba rendezés csak az ajánlatok beérkezése után elemezhető - de akkor már az ajánlati kötöttség miatt a digitális modell csak az értékelési számítások elvégzésében tud segítséget nyújtani.

Gyakori, hogy az ajánlatkérők megszabják az elvárt teljesítési határidőt (pl. szerződéskötést követő legkésőbb 120 naptári napon belül), és az előteljesítést minőségi értékelési szempontként értékelik. Itt nem a minőség játszik szerepet, hanem esetleges költség-csökkentés (ui. egy alacsonyabb fogyasztású jármú korábbi üzembeállitása korábbi tehát több megtakarítást eredményez). Ugyanakkor az előteljesítés értékelése gazdaságilag igen előnytelen is lehet.

Mint minden modellezésnél, itt is fontos, hogy elemzésre alkalmas bemenô adatokat adjunk meg, és a következtetéseket ezekre (valamint a modell tulajdonságaira) tekintettel fogalmazzuk meg. Amennyiben nincs általános törvényszerúség, akkor a következtetéseknél közölni kell azok érvényességét - a félreértések elkerülésére. Ugyancsak tudatában kell lenni, hogy a beszerzési eljárások előkészítése során nem lehet tudni, milyen ajánlatok fognak érkezni. A modell extrém input adatok esetén is múködik, de az eredményeinek felhasználhatósága kétséges. A sorba rendezéssel kapcsolatos megfontolásokra is tekintettel kell lenni. Amennyiben egy több minőségi részszempontot tartalmazó beszerzési eljárásban beérkező ajánlatok egy része alacsony áron kínál alkalmas terméket vagy szolgáltatást, más ajánlatok pedig minőségi felárral és a minőségi értékelési követelményekben támasztottak kisebb-nagyobb mértékủ kielégítésével érkeznek, akkor az eljárás előkészítése - az értékelést tekintve - kiegyenlített volt, a piaci ismeretek kellőképpen figyelembevételre kerültek. Viszont, ha minden ajánlattevő vállalja a minőségi szempontok kielégítését, akkor ezzel extra-profitra törekszenek, és ez azt jelzi, hogy ezek a minőségi szempontok az értékelésben a tényleges értéküknél nagyobb súllyal szerepeltek. A digitális modell az eljárás bírálati szakaszában csak, mint a sorrendet megállapító kalkulátor használható, akkor az értékelési szempontrendszeren már nem lehet változtatni. Azonban minden lefolytatott közbeszerzési eljárás során gyúlnek a tapasztalatok, melyeket a hasonló tárgyú következő eljárásban fel lehet használni.

Hazánkban kevés olyan közbeszerzés-kutatás folyt, mely a közbeszerzést gazdálkodástani irányból közelítette. (Zsarnay et al. 1999) A közbeszerzési eljárásoknál 2015. november 1. óta általánosan alkalmazandó minőségi értékelési szempontok hatásait vizsgáltuk az erre a célra készített digitális modell segítségével. Az ajánlatkérők által alkalmazható, a Közbeszerzési Hatóság által támogatott értékelési módszereket átfogóan ismertettük és javaslatokat fogalmaztunk meg alkalmazásukkal kapcsolatban. Konkrét példákon mutattuk be a helyes, illetve célszerütlen értékelési módszereket. A digitális modell a beszerzési eljárások előkészítésében kell, hogy nagy szerepet kapjon, amelyben a Közbeszerzési kisokos is segíthet. Megalapozza a közpénzek hatékony felhasználásának feltételeit azzal, hogy az ajánlatkérő igényeinek ténylegesen legjobban megfelelő, gazdaságilag legelőnyösebb ajánlat legyen a nyertes ajánlat az értékelés során. A modell szükségességét indokolja az is, hogy igen sokféle esetben fordul elő a valóságban is, továbbá, hogy „egyszerü” logikával a komplex (ár és minőségi részszempontokat egyaránt tartalmazó) értékelési rendszer nem tekinthető át, vagy félrevezető eredményt ad. Az egyes minőségi értékelési részszempontok súlyszámainak helyes meghatározása nem a modell feladata - az eljárás tárgya szerinti szakmai előkészités során kell, a modellből nyert tapasztalatok, a piaci ismeretek és a gazdasági érdekek együttes figyelembevételével a megfelelő súlyszámokat meghatározni. 


\section{Hivatkozott források}

[1.] Arató B. (2014): A köz̧beszerzési jog jogorvoslati rendsz̨ere; speciális köz̧besz̨erzési jogviszonyok, p. 7. Letöltés dátuma: 2020. 04. 30. forrás: http://doktori.bibl.u-szeged.hu/2546/1/dr. $\% 20 \mathrm{Arat} \% \mathrm{C} 3 \% \mathrm{~B} 3 \% 20 \mathrm{Bal} \% \mathrm{C} 3 \% \mathrm{~A} 1 \mathrm{zs} \% 20$ disszert $\% \mathrm{C} 3 \% \mathrm{~A} 1 \mathrm{ci} \% \mathrm{C} 3 \% \mathrm{~B} 3$. pdf

[2.] A Közbeszerzési Hatóság 2017 évi országgyúlési beszámolója. Letöltés dátuma: 2019. 02. 20. forrás: http://www.parlament.hu/irom41/00548/00548.pdf

[3.] A Közbeszerzési Hatóság 2016/147.sz. útmutatója alapján. Letöltés dátuma: 2016. 12. 21. forrás: $\quad$ http://www.kozbeszerzes.hu/kozbeszerzes-z/magyar-jogi-hatter/kozbeszerzesihatosag-utmutatoi/

[4.] Közbeszerzési 2015. évi CXLIII. törvény. Letöltés dátuma: 2020. 04. 30. forrás: https://www.kozbeszerzes.hu/torveny/kbt-2015/

[5.] Közbeszerzési 2015. évi CXLIII. törvény. Letöltés dátuma: 2020. 04. 20. forrás: https://www.kozbeszerzes.hu/torveny/kbt-2015//1/2/3/

[6.] Széchenyi 2020 - Útmutató a Kbt. 77. \(1) bekezdése szerinti legkedvezőbb szint, illetve legkedvezőtlenebb elvárás meghatározásához. Letöltés dátuma: 2017. 07. 25. forrás: https://www.palyazat.gov.hu/tmutat-a-kbt-77-1-bekezdse-szerinti-legkedvezbb-szint-illetvelegkedveztlenebb-elvrs-meghatrozshoz

[7.] Közbeszerzési kisokos: www.közbeszerzes.hu. Letöltés dátuma: 2020. 04. 20. forrás: https://www.kozbeszerzes.hu/kisokos/beszerzesi-targyak-targyi-hataly/szolgaltatasmegrendelese/

[8.] Szabó A. (2018): A Közbeszerzési Hatóság aktuális állásfoglalásai Köz̧besz̧erzési Sz̧emle 6. 20.p. Letöltés dátuma: 2017. 07. 15. forrás: https://www.kozbeszerzes.hu/cikkek/kozbeszerzesiszemle-2018vi-szam

[9.] Tátrai T. (2007): A kǫ̈̋beszerzés, mint sajátos beszerzési tevékenység. Logisztikai évkönyv, 2007. 13. évf. p. 10.

[10.] Török Á. - Győrffy Á. - Hernádi I. (2007): Közbeszerzés, piacmúködés és az állami pénzügyi érdekek védelme; Pénzü̈gyi Szemle, 52 (1), 6.

[11.] Zsarnay J. - Gerenday Zs. - Kaszás É. Szerk. (1999): A köz̧beszerzési törvény végrehajtásának elemzése alapján javaslat a haz̨ai ipar fejlesztésére, az ipari szállitások növelésére. Tanulmány. p. 24.

\section{Szerzők}

Szőke Brigitta,

PhD-hallgató

Magyar Agrár- és Élettudományi Egyetem

szoke.bridget@gmail.com

Cuprik Vanda,

munkatárs

Budapesti Gazdasági Egyetem Külkereskedelmi Kar

cuprik.v@gmail.com 